\title{
Inflammatory reaction in patients with acquired bronchiectasis based on the interleukin $1 \alpha$ and interleukin 10 levels measured using the ELISA method
}

Abstract

Andrei Lesan*, Carmen Monica Pop

Iuliu Haţieganu University of Medicine and Pharmacy, 8 Victor Babes Str., 400000 Cluj-Napoca, Romania

English:

The main objective of this study was to determine the relationship between the pro- and anti-inflammatory response based on the interleukin $1 \alpha$ and interleukin 10 levels in the serum of patients with acquired bronchiectasis and healthy controls. This study was conducted on 77 subjects, divided into two lots: one lot comprising 57 patients with the aforementioned bronchiectasis and the second one comprising 20 healthy control subjects. The enzyme-linked immunosorbent assay method was used to perform the spectrophotometry test for the serum to detect and measure interleukin $1 \alpha$ and interleukin 10 levels. The results were significant from a statistical point on view but only in terms of the mean value of interleukin 10 that was much higher in the anti-inflammatory cytokine. Therefore, we can assume that there is a systemic anti-inflammatory reaction to the inflammation caused by bronchiectasis. Interleukin $1 \alpha$ is unspecific, and the values were similar in both groups; therefore, this interleukin should not be researched further in this direction. Future research is open in this field for the analysis of interleukin levels in bronchoalveolar lavage compared to serum levels.

Keywords

bronchiectasis $\cdot$ interleukins $1 \alpha$ and $10 \cdot$ proinflammatory

\section{Răspunsul inflamator la pacienţii cu bronsiectazii bazat pe nivelurile interleukinelor $1 \alpha$ şi 10 măsurate prin metoda ELISA}

Rezumat

Romanian:

Acest studiu a fost realizat pe 77 de subiecți, împărțiti în două loturi: un lot cuprinzând 57 de pacienți cu bronșiectazii și al doilea lot control alcătuit din 20 de subiecți sănătoși. Metoda ÉLISA a fost utilizată pentru a efectua testul de spectrofotometrie din ser pentru a detecta si a măsura nivelurile de interleukine 1 a si 10. Rezultatele au fost semnificative din punct de vedere statistic, dar numai în ceea ce privește valoarea medie a interleukinei 10, care a fost mult mai mare în grupul celor cu bronşiectazii. Prin urmare, putem presupune că există o reacție antiinflamatoare sistemică la inflamația provocată de bronșiectazii. Interleukina 1 nu este specifică, iar valorile au fost similare în ambele grupuri, prin urmare, această interleukină nu ar trebui să fie cercetată în continuare în această direcție. Cercetările viitoare sunt deschise în acest domeniu pentru analiza nivelurilor de interleukină în spălătura bronşică vs nivelurile serice.

Cuvinte-cheie

bronșiectazie $\cdot$ interleukine 1 a și $10 \cdot$ pro-inflamatorii

${ }^{*}$ Corresponding author: Andrei Lesan

E-mail: andrei_lesan@yahoo.com

2 Open Access. ๑ 2019 Lesan and Pop, published by Sciendo

(@) Branc-ND This work is licensed under the Creative Commons Attribution-NonCommercial-NoDerivs 4.0 License. 


\section{Introduction}

Bronchiectasis is an irreversible disease caused by repeated bacterial infections and chronic inflammation. It is still a major cause of respiratory morbidity, but it is a relatively common disease. Mucociliary clearance is impaired, and therefore, the airways are vulnerable to repeated colonization by pathogens (1). The true prevalence of bronchiectasis remains unknown although this disease has been recognized and diagnosed more and more in the past two to three decades (2).That being said, after the development of modern X-ray imaging, especially high-resolution computer tomography, which quickly became the "gold standard", the diagnosis of bronchiectasis has never been as easy, affordable and accessible as it is now. Patients suffering from this disease often exhibit chronic cough with expectoration; dyspnoea, which is progressive; pulmonary function deterioration; recurrent exacerbations (bacterial infections) and a reduced quality of life (QOL), as well as shortened life expectancy $(1,3-6)$. Treatment protocols are not very well defined and remain largely empirical (7), and despite the treatment, patients still present symptoms and lung function alteration (8). Respiratory morbidity and the overall QOL of patients with bronchiectasis remain the most significant aspects of this disease, and it has become abundantly clear that more studies concerning its treatment are urgently needed $(2,9,10)$.

The main treatment for bronchiectasis remains antibiotic therapy. More and more frequently, macrolides are prescribed in the form of long-term treatment to patients with non-cystic fibrosis (CF) bronchiectasis, given their proven efficacy in the management of some chronic inflammatory airway diseases, especially CF and diffuse panbronchiolitis (11-13). Macrolides are an old class of antibiotics with both an antimicrobial and an anti-inflammatory effect $(14,15)$. This repeated cycle of bacterial infections and inflammation in the pathogenesis of bronchiectasis suggest that long-term macrolide therapy could be beneficial in case of these patients by reducing the microbial load and inhibiting inflammation. However, the effect of longterm antibiotics (including macrolides) on bronchiectasis remains unclear and controversial despite the fact that they are largely used and have effect to a certain degree.

Lately, there has been an increased interest in diagnosing bronchiectasis as easily as possible, with emphasis on its evolution and effect on the QOL. In this sense, there have been several attempts to trace certain non-specific and/or specific inflammatory markers in the inflammatory reaction found in patients with bronchiectasis. Some studies have shown that inflammatory (pro- as well as anti-inflammatory) cytokines drawn by infections and recurrent inflammation play a very important role in the pathogenesis of bronchiectasis, but it is not yet clear if their role is to accelerate the development of bronchiectasis or to stop their evolution (16).
Inflammatory cytokines seem to show the most promise in the pathology of bronchiectasis (17). Interleukins are signalling proteins or molecules belonging to the group of cytokines and are mostly secreted by lymphocytes but can also be secreted in small quantities by monocytes, macrophages and endothelial cells (18).

\section{Experimental part}

For the purpose of the study, two groups were formed. The first group included 57 patients with non-cystic fibrosis bronchiectasis diagnosed exclusively by computed tomography (CT), and the second group included 20 control subjects with no previously diagnosed bronchiectasis pathologies who were considered to be healthy individuals, based on the fact that they did not present any symptoms of bronchiectasis (chronic cough, sputum production or progressive dyspnoea).

Table 1 presents an overview of the group of patients in terms of gender, age, leukocytosis, anaemia and the isolated germ that brought the patients to the hospital for admission in the first place. The subjects were selected from the patients of the ClujNapoca Lung Clinic (Clinica de Pneumoftiziologie "Leon Daniello" Cluj-Napoca).

The factors taken into consideration for each subject were age, gender and smoker or non-smoker status. The subjects filled out a form enquiring on their QOL, namely, a modified CAT - COPD assessment test and of course a consent form for the study.

Table 1. Isolated microorganisms.

\begin{tabular}{lc}
\hline Variable & Frequency \\
\hline Gender $(F)$ & $21(36.8 \%)$ \\
Age less than 60 years & $21(36.8 \%)$ \\
Leukocytosis & $7(12.3 \%)$ \\
Anaemia & $11(19.3 \%)$ \\
Isolated microorganism & \\
Gram negative & $13(22.8 \%)$ \\
Oropharyngeal biocenosis & $35(61.4 \%)$ \\
Mycobacterium tuberculosis & $1(1.8 \%)$ \\
Multiple germs & $4(7 \%)$ \\
Gram positive & $1(1.8 \%)$ \\
Cause of bronchiectasis & \\
Other causes & $4(7.02 \%)$ \\
Asthma & $3(5.26 \%)$ \\
COPD & $10(17.54 \%)$ \\
Bronchitis & $10(17.54 \%)$ \\
Pulmonary fibrosis & $25(43.86 \%)$ \\
Tuberculosis & $2(3.51 \%)$ \\
\hline
\end{tabular}

F, female; COPD, chronic obstructive pulmonary disease. 
After a detailed analysis of the medical history, blood samples were taken to perform complete blood counts and serum biochemistry. Sputum samples were taken for bacteriological examination, which included Gram, AFB - acid fast bacilli (BAAR), KB Koch bacilli culture and aerobic culture. Bronchial aspiration fluid to perform GRAM stain and BAAR microscopic examinations for Mycobacterium tuberculosis were also performed for the patients who did not show any bacterial growth from the spontaneous sputum sample or could not provide a good quality sputum sample. The next step referred to paraclinical investigations: spirometry to determine possible ventilatory dysfunctions, exhaled nitride oxide, 6-minute walk test and chest X-ray. Computed tomography was carried out after the general assessment and paraclinical examinations of the patients presenting general symptoms specific to bronchiectasis. This investigation was carried out in all the patients with suspected bronchiectasis, using "multidetector CT", which generates more accurate results than classic $\mathrm{CT}$. After studying the results of the imaging investigation, only the before-mentioned 57 patients remained in the study.

It is worth mentioning that these clinical and paraclinical investigations were carried out independent of this study, which is an observational study and does not condition the diagnostic or therapeutic conduct in case of these patients. The patients diagnosed with bronchiectasis, based on the abovementioned investigations, were given the option to be part of the study. After obtaining their informed consent (approved by the ethic committee of the university), we continued with blood sampling for specific and specialized investigations over the course of the current research. This did not compel to or imply any financial involvement of the patients.

At least two phials of $4 \mathrm{ml}$ whole blood have been sampled from each patient. These were kept at room temperature for at least 30 minutes (60 minutes optimum but with a uniform interval for all the samples). After 30 (namely, 60) minutes, the blood underwent centrifugation for 10 minutes at 1000 rotations per minute, according to the specifications of the manufacturer of the Booster ${ }^{\mathrm{TM}}$ interleukin kits. The resulting supernatant (serum), which needs to amount to a total of $3 \mathrm{ml}$ (optimal amount being $4 \mathrm{ml}$ ) was stored in two phials at $-20^{\circ} \mathrm{C}$, for at least one month, during which sufficient samples were gathered for long-term storage at $-70^{\circ} \mathrm{C}$, until all the samples were gathered for processing.

Enzyme-linked immunosorbent assay (ELISA) spectrophotometry was used to determine the plasmatic levels of interleukin $1 \alpha$ and interleukin 10. Two devices from different manufacturers were used to further increase the accuracy and relevancy of the study. The spectrophotometers used were Biotek and Sunrise having the same characteristics, especially the same bandwidth. This method was preferred in order to allow a comparison between the two readings of the same plate with 96 wells. Conveniently, the results obtained with each of the devices, with two readings for each, were almost identical. Thus, all the micro test tubes (wells) were appropriate, and none of the kits was unusable. It should also be noted that each of the two interleukins has been analysed in duplicate, for the same reason, so that the results are as accurate and precise as possible.

The ELISA technique used represents a molecule (proteins, carbohydrates, etc.) detection method using enzyme-conjugation antigen/antibody complexes. This is a highly sensitive method, and it is expressed in $\mathrm{pg} / \mathrm{ml}$. It may be qualitative or quantitative and uses monoclonal antibodies and enzymes. For this study, the results were expressed in $\mathrm{pg} / \mathrm{ml}$ and were quantitative. The enzymes represent biochemical catalysers, compounds that increase the speed of chemical reactions occurring in biological systems, without being consumed in the process. Thus, we may infer that the intensity of the generated reaction (namely, the staining of the micro test tubes) is directly proportional to the quantity of enzymes in the respective biological product. The biochemical enzymes used in this measurement are peroxidase, alkaline phosphatase, glucose oxidase and G6PH. The biological samples to which this technique is applicable are serum, plasma, urine, stool sample, synovial fluid, Cerebrospinal fluid and bronchoalveolar lavage fluid. However, for our study, we used only serum from patients with acquired bronchiectasis and healthy control subjects.

The SigmaPlot 12.0 program was used for statistical analysis, and the significance was demonstrated with a $p$ value $<0.05$, as it has become a standard approach. For the assessment of the studied data, in addition to the descriptive statistical methods, we used the independent-samples $t$-test for normal distribution variables and the Mann-Whitney $U$ test for variables that were not normally distributed. Logistic regression analysis was used to assess the significant inflammatory reaction in the observed subjects. The ChiSquare test was used to compare the anti-inflammatory and proinflammatory responses in both groups, and the odds ratio (relative risk) with a confidence interval of $95 \%$ was calculated to determine risk factors.

\section{Results}

For a better understanding of the study and of its purpose, the results will be presented in two separate categories: the results for interleukin $1 \alpha$ and the results for interleukin 10 .

\section{Interleukin $1 \alpha$}

This is a proinflammatory interleukin, and it is one of the most unspecific inflammation protein markers. This interleukin was used in the hope that it could demonstrate the accuracy of the study comparing the unspecific general proinflammatory 
response based on this interleukin and the anti-inflammatory one based on interleukin 10 . Table 1 reveals the interleukin $1 \alpha$ average in patients with acquired bronchiectasis compared to the results from the serum of the studied control subjects and its standard deviation.

By applying the $t$-test to determine the statistical value of these results, we obtained a $p$ value of 0.043 . This shows that the statistical relevance of the comparison between the two groups, namely, the subjects with acquired bronchiectasis and the healthy control subjects, is low.

The IL $1 \alpha$ value was not significantly different in the two groups. The highest value obtained in subjects with acquired bronchiectasis was 77.34 , while the highest value in the healthy control group was 67.54 . The minimum value determined for the studied groups was 41.50 in patients with acquired bronchiectasis and 46.78 in healthy control subjects. These results are represented in Chart 1.

There was no clear difference in the interleukin- $1 \alpha$ values between the patient group (acquired bronchiectasis substantiated by CT investigations) and the control group represented by healthy subjects (or who at least exhibit no bronchiectasis). We can go so far as to say that the control group exhibits slightly higher overall values compared to the patient group.

For a better visual perception of the antigen/antibody action that has taken place so that the spectrophotometer could read the lengths of the light beam, we can refer to Figure 1 - photo taken before the wells were analysed.

Table 2. Average IL $1 \alpha$ values and standard deviation.

\begin{tabular}{lcc}
\hline & $\begin{array}{c}\text { Group 1 - patients } \\
\text { with bronchiectasis }\end{array}$ & $\begin{array}{c}\text { Group 2 - healthy } \\
\text { control subjects }\end{array}$ \\
\hline $\begin{array}{l}\text { Average IL1 } \alpha \text { value } \\
(\mathrm{pg} / \mathrm{ml})\end{array}$ & 51.31 & 52.82 \\
Standard deviation & 7.328 & 5.240 \\
\hline
\end{tabular}

\section{II-1 alfa}

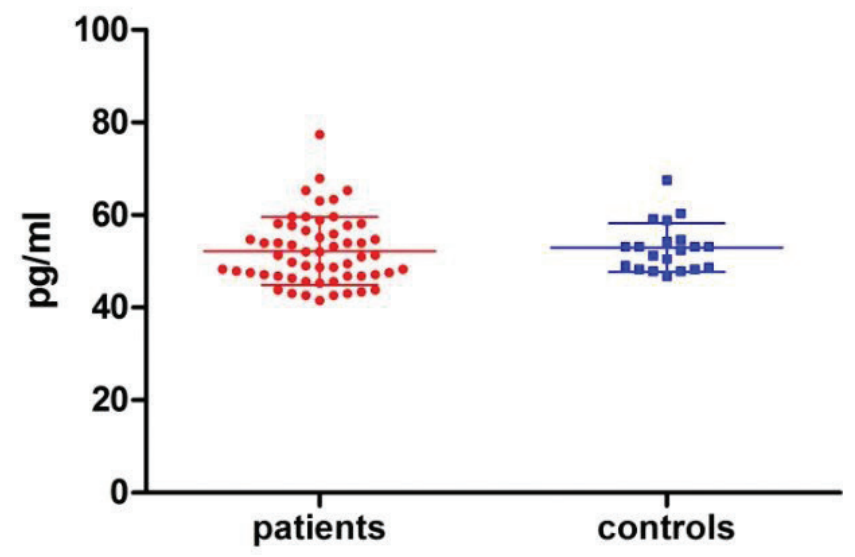

Chart 1

\section{Interleukin 10}

This interleukin is anti-inflammatory by nature, and the mean values obtained for both groups are represented in Table 3 .

The difference in the values of IL 10 obtained in the two groups was statistically significant. The highest value obtained in subjects with acquired bronchiectasis was 53.07, while the highest value in the healthy control group was 48.62 . The minimum value determined for the studied groups was 39.31 in patients with acquired bronchiectasis and 38.77 in healthy control subjects, and the maximum value was 81.93 in the patient group and 60.12 in the control group. The $p$ value for this comparison was 0.13 , which makes this comparison statistically relevant. These results are represented in Chart 2. The main purpose of the present study was to determine whether there is any difference in the plasmatic levels of some specific interleukins in patients with acquired bronchiectasis compared to healthy controls. The study also analysed two sides of the same coin by taking into consideration the differences in both anti-inflammatory and proinflammatory interleukins.

\section{Discussion}

Chronic inflammation and recurrent infections are the foundation of the disease called bronchiectasis. As expected, the response of the organism is one of inflammatory nature and can be a very significant one for that matter. The inflammatory response is translated into the serum as the release of specific inflammation proteins such as IL-6, IL-8

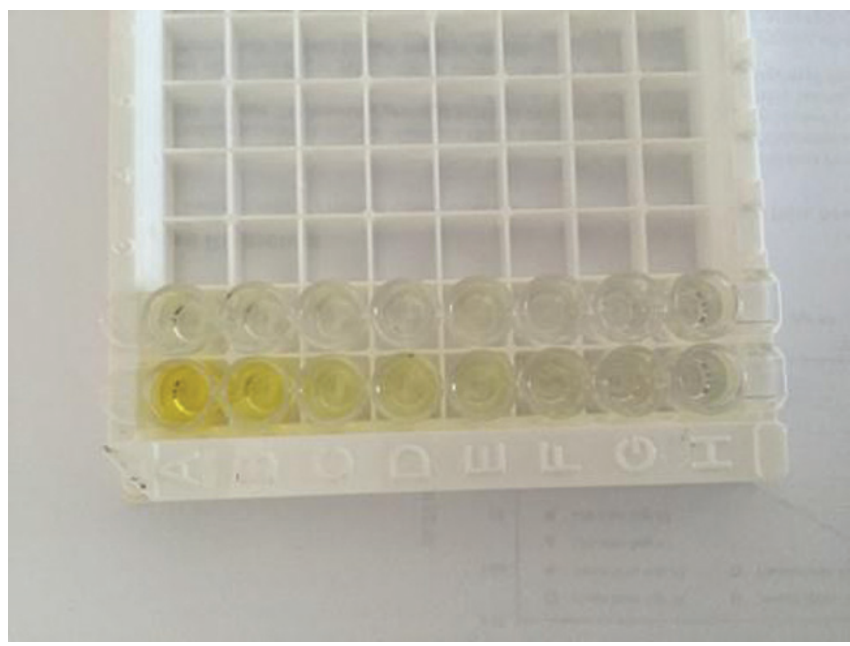

Figure 1.

Table 3. Average IL10 values and standard deviation.

\begin{tabular}{lcc}
\hline & $\begin{array}{c}\text { Group 1 - patients } \\
\text { with bronchiectasis }\end{array}$ & $\begin{array}{c}\text { Group 2 - healthy } \\
\text { control subjects }\end{array}$ \\
\hline $\begin{array}{l}\text { Average IL10 value } \\
(\mathrm{pg} / \mathrm{ml})\end{array}$ & 53.07 & 48.62 \\
\hline
\end{tabular}




\section{IL-10 ELISA}

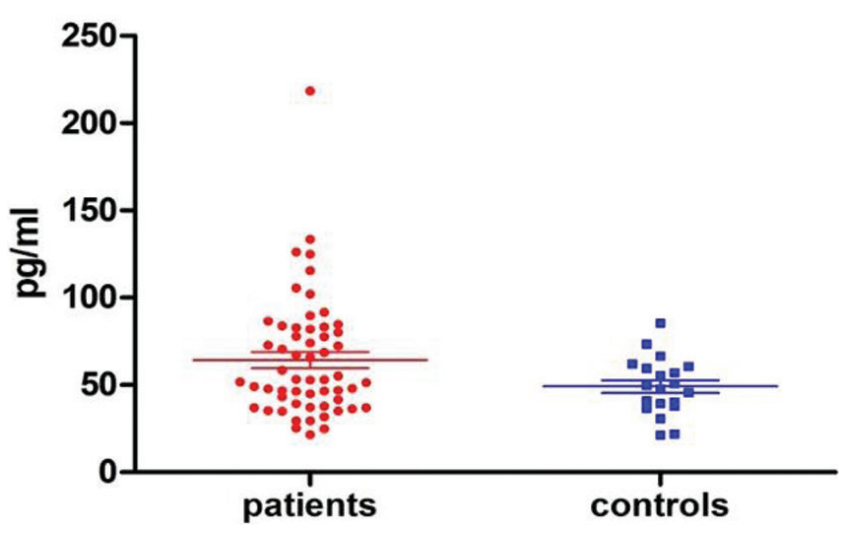

Chart 2

and leukotriene. (19). The response mentioned before is one of proinflammatory nature and is to be expected in patients with an acquired form of bronchiectasis.

Some recent studies have shown that there is a significant difference in anti-inflammatory interleukins in patients with acquired bronchiectasis compared to healthy subjects. In one study, the authors opted to analyse interleukin 4 and interleukin 6 and also anti-inflammatory and proinflammatory cytokines. The results of the study were interesting in the sense that there were significant differences in the group with bronchiectasis compared to the healthy group. The conclusion of the study was that there seems be a certain immunosuppressive condition in patients with acquired bronchiectasis (20), which remains to be seen after more in-depth tests (particularly, bronchoalveolar lavage interleukin measurements) are performed on subjects with acquired bronchiectasis.

As an example of the in vivo applicability of interleukins, there is a specific but also multifunctional interleukin responsible for the stimulation of mucus hypersecretion. Some studies have found that interleukin 4 is one of the major interleukins responsible for this hyperreaction by stimulating the mucussecreting tissue but that it is also linked to $B$ lymphocytes (21). Bronchiectasis just like COPD is frequently associated with smoking, and given the exposure to this inhaled irritant, there will always be a chronic pulmonary inflammation, hence the elevated serum levels of interleukins. The relation between $C$-reactive protein and the plasmatic levels of some interleukins (e.g. IL-6) has been studied only in relation to COPD revealing that it can be connected to some phenotypes of this disease, especially the acute-phase proteins. The biggest problem that remains is that it is practically impossible to completely exclude the non-disease-related factors such as lifestyle and/ or socioeconomic conditions $(22,23)$.

Moststudies of interleukin plasmatic levels (especially, interleukin 4 and interleukin 12) are performed on chronic pulmonary diseases such as COPD, chronic bronchitis and asthma.
The most extensive studies are on and about asthma and the key proteins in the allergic response. Fewer studies also show the relation between the smoking behaviour in COPD, as well as in chronic bronchitis, and the plasmatic levels of these interleukins (24). These interleukins are an acute reaction to the smoking habit and exposure, which is why in ex-smokers with COPD, there is no plasmatic increase that can be of relevance to the severity or even clinical profile of the disease $(25,26)$. Looking over the specific literature, there are no relevant studies of the plasmatic levels of pro- or anti-inflammatory interleukins in the bronchiectasis disease, but we can find some correspondence between chronic bronchitis, COPD and smoking given the fact that these pathologies intertwine on many occasions aggravating each other. The main idea that can be drawn is that there is still an overall increase in plasmatic inflammatory (proand anti-inflammatory) cytokines in all the chronic pulmonary inflammatory diseases including bronchiectasis.

The fact that there is a relation between these inflammatory proteins and pulmonary inflammatory diseases and the smoking behaviour leads to the main finding that there is a possible cytokine involvement in the evolution of bronchiectasis. There is a study that shows the direct involvement of interleukin 4 in goblet cell metaplasia with a direct effect on airway epithelial cells (27).

\section{Conclusions}

Interleukin $1 \alpha$ measurements have proven that there is no significant difference between the two groups. However, this was to be expected considering that it is a "broad spectrum" interleukin with a proinflammatory role. This can support the idea that there is always an active inflammatory process somewhere in the human body and it is involved not solely in the bronchiectasis-induced inflammation but also in unspecific proinflammatory systemic reactions and should not be considered for future studies in this direction.

On the other hand, the value of interleukin 10 is higher in the group of patients with acquired bronchiectasis compared to the healthy control group. Given the fact that this specific interleukin has an anti-inflammatory role, we can observe that out of the two proteins studied, the anti-inflammatory reaction is the most active one.

Thus, this study infers that patients with acquired bronchiectasis exhibit a systemic reaction to the inflammation caused by the disease and tend to reduce this process by releasing proteins with anti-inflammatory properties meant to reduce the process. Clearly, at this time, we cannot state with certainty that this interleukin reacted purely because of the bronchiectasis, but still the difference between the groups is significant.

This inflammatory phenomenon, as well as a better staging and assessment of the evolution of bronchiectasis, could be 
better understood and mapped if there were a subsequent study based on more than two interleukins and these proteins were analysed from the bronchoalveolar lavage, as well as from the serum of patients with diagnosed acquired bronchiectasis compared to that of healthy controls.

\section{Ethics approval and consent to participate}

Inform consent was obtained from the patients in order to participate to the study and write the article.

\section{References}

1. Martinez-Garcia MA, Perpina-Tordera $M$, Roman-Sanchez $P$, Soler-Caraluna JJ. Quality-of-life determinants in patients with clinically stable bronchiectasis. Chest. 2005;128: 739-745.

2. Smith MP. Non-cystic fibrosis bronchiectasis. The Journal of Royal College of Physicians of Edinburgh. 2011;41: 132-139; quiz 139.

3. Barker AF. Bronchiectasis. The New England Journal of Medicine. 2002;246: 1383-1393.

4. Chalmers JD, Smith MP, McHugh BI, Doherty C, Govan JR, Hill AT. Shrt- and long-term antibiotic treatment reduces airway and systemic inflammation in non-cystic fibrosis bronchiectasis. American Journal of Respiratory and Critical Care Medicine. 2012:186: 657-665.

5. Loeinger MR, Wells AU, Hansell DM, Chinyanganya N, Devajan A., Meister M, et al. Mortality in bronchectasis: A long term study assessing the factors influencing survival. European Respiratory Journal. 2009;34: 843-849.

6. Roberts ME, Lowndes L, Milne DG, Wong CA. Socioeconomic deprivation, readmission, mortality and acute exacerbation of bronchiectasis. Internal Medicine Journal. 2012;42: e129-e136.

7. Pasteru MC, Bilton D, Hill AT, British Thoracic Society Bronchiectasis non-CF Guideline Group. British Thoracic Society guideline non-CF bronchiectasis. Thorax. 2010;65(Suppl. 1): 11-58.

8. Weycker D, Edelsberg J, Oster G, Tino G. Prevalence and economic burden of bronchiectasis. Clinical Pulmonary Medicine. 2005;12: 205-209.

9. King P, Holds Worth S, Freezer N, Holmes P. Bronchiectasis. Internal Medicine Journal. 2006;36: 729-737.

10. Cumbaia AA, Edmonds LC, Bauer MA, Jederlinic PJ, May JJ, Victory IM, et al. The disease-modifying effects of twice-weekly oral azithromycin in patients with bronchiectasis. Treatments in Respiratory Medicine. 2005;4: 117-122.

11. Crosbie PAJ, Woodhead MA. Long-term macrolide therapy in chronic inflammatory airway diseases. European Respiratory Journal. 2009;33: 171-181.

12. Kudoh S, Azuma A, Yamamoto M, Izumi T, Ando M. Improvement of survival in patients with diffuse panbronchiolitis treated with low-dose erythromycin. American Journal of Respiratory and Critical Care Medicine. 1998;157(6 pt 1): 1829-1832.
13. Serieri DJ, Martin ML. Long-term, low-dose erythromycin in bronchiectasis subjects with frequent infective exacerbations. Respiratory Medicine. 2011;105: 946-949.

14. Friedlander AL, Albert RK. Chronic macrolide therapy in inflammatory airways diseases. Chest. 2010;138: 1202-1212.

15. Zarogoulidis P, Papanas N, Kioumis I, Chatzaki E, MAltezos E, Zarogoulidis K. Macrolides from in vitro anti-inflammatory and immunomodulatory properties to clinical practice in respiratory diseases. European Journal of Clinical Pharmacology. 20121;68: 479-503.

16. Boyton JR, Altmann DM. Bronchiectasis: Current concepts in pathogenesis, immunology, and microbiology. Annual Reviews of Pathology: Mechanisms if Disease, 2016;11: 523-554. [https://www.annualreviews.org/doi/10.1146/annurev-pathol012615-044344 accessed online on 23.06.2018].

17. Ho JC, Tipoe G, et al, In vitro study of regulation on IL-6 production in bronchiectasis. Respiratory Medicine. 2014;98(4): 334-341.

18. Torrado E, Cooper AM. Cytokines in the balance of protection and pathology during mycobacterial infections. Advances in Experimental Medicine and Biology. 2013;783: 121-140.

19. King TP. The role of the immune response in the pathogenesis of bronchiectasis. BioMed Research International. 2018;2018: 12.

20. Andrei L, Milena AM, Roxana MN, Tudor H, loan ST, Beatrice $M B$, et al. Serum interleukin 4 and 6 levels measured using the ELISA method in patients with acquired bronchiectasis compared to healthy subjects. An anti-inflammatory and pro-inflammatory relation. Revista de Chimie. 2019;70: 2411-2414.

21. Zhu J, Qiu Y, Valobra M, Qiu S, Majumdar S, Matin D, De Rose $\mathrm{V}$, Jeffery PK. Plasma cells and IL-4 in chronic bronchitis and chronic obstructive pulmonary disease. American Journal of Respiratory and Critical Care Medicine. 2007;175(11): 1125-1133.

22. Yanbaeva DG, Dentener MA, Spruit MA, Houwing-Duistermaat, JJ, Kotz D, Passos VL, et al. IL6 and CRP haplotypes are associated with COPD risk and systemic inflammation: A case-control study. BMC Medical Genetics. 2009;10: 23.

23. Nitescu M, Furtunescu FL, Otelea M, Rafila A, Streinu-Cercel A. Prevalence of metabolic syndrome parameters in a Romanian population of young adults. Revista Romana de Medicina de Laborator. 2012;20(3): 21-28.

24. Miotto D, Ruggieri MP, Boschetto P, Cavallesco G, Papi A, Bononi I, et al. Interleukin-13 and -4 expression in the central airways of smokers with chronic bronchitis. European Respiratory Journal. 2003;22(4): 602-608.

25. De Moraes MR, Da Costa AC, Correa Kde S, Junqueira- Kipnis AP, Rabahi MF. Interleukin-6 and interleukin-8 blood levels' poor association with the severity and clinical profile of ex-smokers with COPD. International Journal of Chronic Obstructive Pulmonary Disease. 2014;9: 735-743.

26. Ianosi ES, Postolache P, Macovei LA, Szathmary M, Szasz S, Nemes RM, et al. Smoking cessation in COPD patients by a selective partial nicotinic agonist. Revista de Chimie. 2018;69(7): 1766-1769.

27. Dabbagh K, Takeyama K, Lee HM, Ueki IF, Lausier JA, Nadel JA IL 4 induces mucin gene expression and goblet cell metaplasia in vitro and in vivo. The Journal of Immunology. 1999;162: 6233-6237. 